\title{
Assessments Effect of Nitrogen and Phosphorus on the Phenological and Fruit Characters of Okra (Abelmoschus esculentus L.)
}

\author{
Chandan Singh Ahirwar*, Avadhesh Pratap Singh, Ravindra Nath and P. Verty \\ School of Agriculture, ITM University, Gwalior, Madhya Pradesh, India \\ *Corresponding author
}

\section{A B S T R A C T}

\section{Keywords}

Nitrogen, Phosphorus, Okra (Abelmoschus esculentus L.) Fruit length, Fruit diameter, Fruit yield

\section{Article Info}

Accepted:

17 January 2021

Available Online:

10 February 2021
An experiment was conducted at Horticultural Research Farm, School of Agriculture, ITM University, Gwalior, during summer 2019 to evaluate the effect of nitrogen and phosphorus on growth and yield of lady finger. The experiment was laid out in Randomized Complete Block Design with factorial arrangement having three replications. The treatment consisted of four nitrogen level sand three phosphorus levels. The results of experiment revealed that the different nitrogen and phosphorus levels, both significantly affected the various phonological characters viz., number of days to first flowering, number of days taken to 50 per cent flowering, number of days taken of first fruit picking, fruit characters like fruit length, diameter of the fruit, numbers of fruits per plant and fruit yield per hectare. The treatment combination consisting of application of nitrogen @ 150 $\mathrm{kg} / \mathrm{ha}$ with combined application of phosphorus @ $75 \mathrm{~kg} / \mathrm{ha}$ produced significantly maximum number of days to first flowering (46.48), number of days taken to 50 per cent flowering (48.17), number of days taken of first fruit picking (54.84), fruit length (15.66 $\mathrm{cm})$. While, the treatment combination consisting of application of nitrogen @ $150 \mathrm{~kg} / \mathrm{ha}$ with combined application of phosphorus @ $100 \mathrm{~kg} / \mathrm{ha}$ produced significantly maximum diameter of fruits $(2.36 \mathrm{~cm})$, number of fruits per plant (22.36) and fruit yield per hectare (17.77) at maximum crop growth stage followed by application of nitrogen @ $150 \mathrm{~kg} / \mathrm{ha}$ with combined application of phosphorus@ $75 \mathrm{~kg} / \mathrm{ha}$ as compared to all the remaining treatment combinations. It is concluded that application of optimum level of nitrogen@ $150 \mathrm{~kg} / \mathrm{ha}$ with combined application of phosphorus @ $100 \mathrm{~kg} / \mathrm{ha}$ recorded the maximum plant growth and fruit yield of okra.

\section{Introduction}

Okra (Abelmoschus esculentus (L.) Moench) commonly known as lady's finger or bhindi, belongs to the family Malvaceae. It is widely adopted vegetable in Indian kitchens and can be grown round the year. Besides the utility of its tender green fingers as a vegetable, it is used in soups and curries. India ranks first in the world with the production of 3.5 million tonnes (70\% of the total world production) from an area of 0.35 million ha (Veer Bhan Singh and Anil Kumar Tiwari, 2019). In Madhya Pradesh it occupies about 26510 hectares with total production of 305910 MT/ha. The green fruits contain numerous 
white seeds when immature. The beautiful flowers and upright stature give okra an ornamental value. Dry seeds of okra contain 18- $20 \%$ oil and 20-30\% crude protein. Okra seeds contain many mono- unsaturated fatty acids viz., oleic and palmitic acid. Okra is a short duration crop and produces fruits continuously for a longer time thus its growth, yield and quality are largely influenced by nutrient management practices.

The yield gap indicates that there is better scope for enhancing the productivity of okra in Madhya Pradesh. Among the various factors influencing successful production of okra, the judicious nutrients application is of vital importance. Fertilizers are generally applied to improve crop yield, nutritional quality (Sikander et al., 2009). Nitrogen, phosphorus and potash are major nutrients required by plants for their proper growth and development for getting higher yields. Nitrogen and phosphorus perform different functions in crop growth and development and they cannot be substituted by any other factors or element. Nitrogen is an important constituent of chlorophyll and required for synthesis of protein, nucleic acids and pigments. Nitrogen is needed by plants in large amounts. It is essential element for vigorous growth, branching, leaf development, root expansion, high photosynthetic activity and formation of protoplasm and for these reasons in turn increases crop yield and improves quality. Nitrogen fertilizer use in vegetable cultivation is increased by 21 per cent between 1997 and 2003 (Mubashir et al., 2010). Several workers have reported linear increase in green pod yield of okra with the application of nitrogen from 56 to $150 \mathrm{~kg}$ per hectare.

Phosphorus is another key element in the formation of high energy compounds such as Adenosine monophosphate, Adenosine diphosphate and Adenosine triphosphate and there by contributing to increased yield and quality of crops. It also plays essential role in photosynthesis and respiration. It is necessary for energy transformation in plant cells, cell division, development of meristematic tissues, early root development, tillering, flowering and seed development (Memon, 1996). Its improved root growth, hastened seed maturity and increases fruit yield especially when applied in combination with nitrogen (Pandey and Dubey, 1996).

The interaction of these nutrient elements may affect the critical levels of available nitrogen and phosphorus below which response to their application could be observed. Information on effect of combined application of nitrogen and phosphorus on growth, yield, and quality of each nutrient in okra is rather limited in the sub-tropical zone of M.P. Keeping these points in view, the present investigations were under taken.

\section{Materials and Methods}

The experiment was carried out at Horticultural Research Farm, School of Agriculture, ITM University, Gwalior, (M.P.) during the summer season of 2019. The experiment was conducted in randomize complete block design having Factorial concept with three replications. Different rates of nitrogen and phosphorus allocated to the plots as per treatments.

The treatments were four levels of nitrogen levels viz., $75 \mathrm{~kg} / \mathrm{ha}\left(\mathrm{N}_{1}\right), 100 \mathrm{~kg} / \mathrm{ha}\left(\mathrm{N}_{2}\right), 125$ $\mathrm{kg} / \mathrm{ha}\left(\mathrm{N}_{3}\right)$ and $150 \mathrm{~kg} / \mathrm{ha}\left(\mathrm{N}_{4}\right)$ with three phosphorus levels viz., $50 \mathrm{~kg} / \mathrm{ha}\left(\mathrm{P}_{1}\right), 75 \mathrm{~kg} / \mathrm{ha}$ $\left(\mathrm{P}_{2}\right)$ and $100 \mathrm{~kg} / \mathrm{ha}\left(\mathrm{P}_{3}\right)$. The gross and net plot size was $3.6 \mathrm{~m} \times 3.6 \mathrm{~m}$ and $3.3 \mathrm{~m} \mathrm{x} 3.0$ $\mathrm{m}$, respectively. The fertilizers grades were applied as per treatments. The recommended dose of potassium was applied @ $50 \mathrm{~kg} \mathrm{~K}_{2} \mathrm{O}$ / ha while, nitrogen $(\mathrm{N})$ and phosphorus $\left(\mathrm{P}_{2} \mathrm{O}_{5}\right)$ was applied as per the treatments. All the 
other agronomic practices were applied uniformly to all the treatments.

\section{Results and Discussion}

The result shows that phenological characters of okra viz., number of days to first flowering, number of days taken to 50 per cent flowering, number of days taken of first fruit picking, fruit characters like fruit length, diameter of the fruit and numbers of fruits per plant was influenced significantly due to different concentrations of nitrogen and phosphorus.

Data regarding these characters are reported in (Table 1). Statistical analysis of the data revealed that maximum number of days to first flowering (43.09), number of days taken to 50 per cent flowering (44.91), number of days taken of first fruit picking (53.18), fruit characters like fruit length $(14.87 \mathrm{~cm})$, diameter of the fruit $(1.99 \mathrm{~cm})$ and numbers of fruits per plant (21.71) were recorded when plots treated with the application of nitrogen @ $150 \mathrm{~kg} / \mathrm{ha}\left(\mathrm{N}_{4}\right)$ while, lowest values were observed in plot that received nitrogen @75 $\mathrm{kg} / \mathrm{ha}$. Application of phosphorus @ $50 \mathrm{~kg} / \mathrm{ha}$ gave maximum number of days to first flowering, number of days taken to 50 per cent flowering and number of days taken of first fruit picking with the respective of 42.88,44.61 and53.05, respectively. While, Application of phosphorus @ $100 \mathrm{~kg} / \mathrm{ha}$ gave highest fruit length $(14.06 \mathrm{~cm})$, diameter of the fruit $(1.75 \mathrm{~cm})$ and numbers of fruits per plant (17.31).

Statistical analysis of data revealed that interaction effect of nitrogen and phosphorus significantly affected to phenological and fruit characters ultimately fruit yield was found significant. Similarly, in interaction the maximum number of days to first flowering (46.48), number of days taken to 50 per cent flowering (48.17) and number of days taken of first fruit picking (54.84) was recorded from plot receiving nitrogen @ $150 \mathrm{~kg} / \mathrm{ha}$ combined application with phosphorus@50 $\mathrm{kg} / \mathrm{ha}$, while minimum values were recorded under the application of nitrogen @ $75 \mathrm{~kg} / \mathrm{ha}$ with application of phosphorus @ 50 kg/ ha.

Fruit characters like fruit length $(15.66 \mathrm{~cm})$, diameter of the fruit $(2.36 \mathrm{~cm})$ and numbers of fruits per plant (22.36)was recorded from plot receiving nitrogen @ 150 $\mathrm{kg} / \mathrm{ha}$ combined application with phosphorus @ $100 \mathrm{~kg} / \mathrm{ha}$, while minimum values were recorded under the application of nitrogen @ $75 \mathrm{~kg} / \mathrm{ha}$ with application of phosphorus @ 50 $\mathrm{kg} / \mathrm{ha}$.

The data related to flowering was delayed when nitrogen was applied at $150 \mathrm{~kg}$ per hectare and flowering was early at when nitrogen was applied at $75 \mathrm{~kg}$ per hectare. This may be due to the fact that excessive supply of nitrogen promotes luxuriant and succulent vegetative growth dominating the reproductive phase. These results are in agreement with the findings of Khan et al., (2010). $\mathrm{P}_{2} \mathrm{O}_{5}$ @ 100kg/ha took minimum number of days for days to first flowering and also for fifty per cent flowering, since phosphorus enhances development of reproductive parts and stimulates early blooming. These results are in line with that of Bhende et al., (2015) who reported that number of days to flowering was reduced by phosphorus and increased by nitrogen in okra.

The crop took a smaller number of days to first fruit picking when nitrogen was applied in reducing doses. It might be due to the fact that high level of nitrogen prolonged the growing period with consequent delay in maturity. Although nitrogen tends to delay fruiting but various nitrogen levels when combined with constant doses of nitrogen and phosphorus gave significant effect. The reason might be its combination with nitrogen 
and phosphorus, because nitrogen increases days to fruiting, while phosphorus brings early maturity of crops. These results were in conformity with the finding of Khan et al., (2013), Yadav et al., (2016) and Narendra et al., (2017).

The fruit characters viz., fruit length and girth, number of fruits per plant as in influenced by different levels of nitrogen is presented in result table 1 . The highest number of fruits per plant might be due to vigour of plant. Higher dose should ordinarily be instrumental in enhancing plant growth and affect consequently the fruit number. These results are in agreement with Bairwa et al., (2009) and Srivastava et al., (2009). The increased fruit characters may be due to higher dose of nitrogen might have enhanced cell division and formation of more tissues resulting in luxuriant vegetative growth thereby increased fruit characters. These results were in conformity with Firoz (2009) and Khan et al., (2010). Significantly highest fruit length and number was recorded when nitrogen was applied at $150 \mathrm{~kg}$ per hectare. This may be due to increased absorption of nitrogen which resulted in increased synthesis of carbohydrates which are utilized in building up of new cells. These results are in accordance with the reports of Shelar et al., (2011).

Table.1 Influence of effect of nitrogen levels on growth and yield of lady finger

\begin{tabular}{|c|c|c|c|c|c|c|c|}
\hline Treatment & $\begin{array}{l}\text { Number } \\
\text { of days } \\
\text { to first } \\
\text { flowering }\end{array}$ & $\begin{array}{l}\text { Number of } \\
\text { days taken } \\
\text { to } 50 \text { per } \\
\text { cent } \\
\text { flowering }\end{array}$ & $\begin{array}{l}\text { Number } \\
\text { of days } \\
\text { taken of } \\
\text { first fruit } \\
\text { picking }\end{array}$ & $\begin{array}{l}\text { Fruit } \\
\text { length } \\
\text { (cm) }\end{array}$ & $\begin{array}{l}\text { Fruit } \\
\text { diameter } \\
(\mathrm{cm})\end{array}$ & $\begin{array}{l}\text { Numbers } \\
\text { of fruits } \\
\text { per plant }\end{array}$ & $\begin{array}{l}\text { Fruit } \\
\text { yield per } \\
\text { hectare } \\
\text { (q/ha) }\end{array}$ \\
\hline $\mathbf{N}_{1}$ & 39.61 & 41.39 & 49.56 & 11.11 & 1.36 & 11.06 & 10.70 \\
\hline $\mathbf{N}_{2}$ & 40.86 & 42.32 & 50.52 & 13.74 & 1.50 & 13.78 & 12.73 \\
\hline $\mathbf{N}_{3}$ & 41.23 & 42.90 & 51.93 & 14.26 & 1.60 & 18.36 & 14.52 \\
\hline $\mathbf{N}_{4}$ & 43.09 & 44.91 & 53.18 & 14.87 & 1.99 & 21.71 & 16.59 \\
\hline S. Em \pm & 0.44 & 0.34 & 0.42 & 0.17 & 0.05 & 0.24 & 0.11 \\
\hline CD & 1.29 & 1.00 & 1.23 & 0.51 & 0.15 & 0.71 & 0.32 \\
\hline
\end{tabular}

Table.2 Influence of effect of phosphorus levels on growth and yield of lady finger

\begin{tabular}{|c|c|c|c|c|c|c|c|}
\hline Treatment & $\begin{array}{c}\text { Number } \\
\text { of days } \\
\text { to first } \\
\text { flowering }\end{array}$ & $\begin{array}{c}\text { Number of } \\
\text { days taken } \\
\text { to } 50 \text { per } \\
\text { cent } \\
\text { flowering }\end{array}$ & $\begin{array}{l}\text { Number } \\
\text { of days } \\
\text { taken of } \\
\text { first fruit } \\
\text { picking }\end{array}$ & $\begin{array}{l}\text { Fruit } \\
\text { length } \\
\text { (cm) }\end{array}$ & $\begin{array}{c}\text { Fruit } \\
\text { diameter } \\
(\mathrm{cm})\end{array}$ & $\begin{array}{l}\text { Numbers } \\
\text { of fruits } \\
\text { per plant }\end{array}$ & $\begin{array}{c}\text { Fruit } \\
\text { yield per } \\
\text { hectare } \\
\text { (q/ha) }\end{array}$ \\
\hline $\mathbf{P}_{1}$ & 42.88 & 44.61 & 53.05 & 12.89 & 1.48 & 14.86 & 12.73 \\
\hline $\mathbf{P}_{2}$ & 41.45 & 43.17 & 52.20 & 13.55 & 1.60 & 16.51 & 13.71 \\
\hline $\mathbf{P}_{3}$ & 39.26 & 40.86 & 48.64 & 14.06 & 1.75 & 17.31 & 14.47 \\
\hline S. Em \pm & 0.38 & 0.30 & 0.36 & 0.15 & 0.04 & 0.21 & 0.09 \\
\hline CD & 1.12 & 0.87 & 1.06 & 0.44 & 0.13 & 0.61 & 0.28 \\
\hline
\end{tabular}


Table.3 Influence of effect of between nitrogen and phosphorus on growth and yield of lady finger

\begin{tabular}{|l|c|c|c|c|c|c|c|}
\hline Treatment & $\begin{array}{c}\text { Number } \\
\text { of days to } \\
\text { first } \\
\text { flowering }\end{array}$ & $\begin{array}{c}\text { Number of } \\
\text { days taken } \\
\text { to 50 per } \\
\text { cent } \\
\text { flowering }\end{array}$ & $\begin{array}{c}\text { Number } \\
\text { of days } \\
\text { taken of } \\
\text { first fruit } \\
\text { picking }\end{array}$ & $\begin{array}{c}\text { Fruit } \\
\text { length } \\
\text { (cm) }\end{array}$ & $\begin{array}{c}\text { Fruit } \\
\text { diameter } \\
\text { (cm) }\end{array}$ & $\begin{array}{c}\text { Numbers } \\
\text { of fruits } \\
\text { per plant }\end{array}$ & $\begin{array}{c}\text { Fruit } \\
\text { yield per } \\
\text { hectare } \\
\text { (q/ha) }\end{array}$ \\
\hline $\mathbf{N}_{\mathbf{1}} \mathbf{P}_{\mathbf{1}}$ & 41.68 & 43.17 & 52.17 & 9.80 & 1.18 & 9.52 & 9.81 \\
\hline $\mathbf{N}_{\mathbf{1}} \mathbf{P}_{\mathbf{2}}$ & 40.78 & 42.50 & 51.67 & 11.43 & 1.44 & 11.42 & 10.66 \\
\hline $\mathbf{N}_{\mathbf{1}} \mathbf{P}_{\mathbf{3}}$ & 36.35 & 38.51 & 44.84 & 12.10 & 1.45 & 12.25 & 11.63 \\
\hline $\mathbf{N}_{\mathbf{2}} \mathbf{P}_{\mathbf{1}}$ & 41.42 & 43.27 & 52.54 & 13.19 & 1.47 & 13.02 & 12.26 \\
\hline $\mathbf{N}_{\mathbf{2}} \mathbf{P}_{\mathbf{2}}$ & 41.02 & 42.84 & 51.84 & 13.96 & 1.48 & 14.16 & 12.87 \\
\hline $\mathbf{N}_{\mathbf{2}} \mathbf{P}_{\mathbf{3}}$ & 40.13 & 40.84 & 47.17 & 14.08 & 1.55 & 14.17 & 13.07 \\
\hline $\mathbf{N}_{\mathbf{3}} \mathbf{P}_{\mathbf{1}}$ & 41.94 & 43.84 & 52.67 & 14.13 & 1.56 & 16.00 & 13.36 \\
\hline $\mathbf{N}_{\mathbf{3}} \mathbf{P}_{\mathbf{2}}$ & 41.55 & 43.17 & 51.95 & 14.28 & 1.59 & 18.62 & 14.78 \\
\hline $\mathbf{N}_{\mathbf{3}} \mathbf{P}_{\mathbf{3}}$ & 40.20 & 41.70 & 51.17 & 14.38 & 1.64 & 20.46 & 15.42 \\
\hline $\mathbf{N}_{\mathbf{4}} \mathbf{P}_{\mathbf{1}}$ & 46.48 & 48.17 & 54.84 & 14.43 & 1.72 & 20.91 & 15.48 \\
\hline $\mathbf{N}_{\mathbf{4}} \mathbf{P}_{\mathbf{2}}$ & 42.44 & 44.17 & 53.34 & 14.53 & 1.89 & 21.86 & 16.52 \\
\hline $\mathbf{N}_{\mathbf{4}} \mathbf{P}_{\mathbf{3}}$ & 40.35 & 42.38 & 51.37 & 15.66 & 2.36 & 22.36 & 17.77 \\
\hline $\mathbf{S . E m} \pm$ & 0.76 & 0.59 & 0.73 & 0.30 & 0.09 & 0.42 & 0.19 \\
\hline $\mathbf{C} \mathbf{E}$ & 2.23 & 1.73 & 2.13 & 0.88 & 0.26 & 1.22 & 0.55 \\
\hline
\end{tabular}

Significant increase in fruit characters with the higher level of phosphorus may be due to the phosphorus involvement in energy transformation in plant cells, cell division, development of meristematic tissues, early root development and branching. Thus, the increase in nitrogen and phosphorus supply, accelerate synthesis of growth hormones in plants which indirectly exhibited by enhanced grow the plants and their parts. These results were in conformity with the finding of Yadav et al., (2016) and Narendra et al., (2017) (Table 2).

Statistical analysis of the data revealed that highest fruit yield (16.59 t/ha) were recorded in plots treated with the application of nitrogen @ $150 \mathrm{~kg} / \mathrm{ha}\left(\mathrm{N}_{4}\right)$ while, lowest values (10.70 t/ha) were observed in plot that received nitrogen @ $75 \mathrm{~kg} / \mathrm{ha}$. Similarly, application of phosphorus @ $100 \mathrm{~kg} / \mathrm{ha}$ gave highest fruit yield (14.47 t/ha) (Table 3).
Similarly, data revealed that interaction effect of nitrogen and phosphorus significantly affected fruit yield was found significant. In interaction effect, the highest fruit yield (17.77 t/ha) was recorded from plot receiving nitrogen@150 kg/ha combined application with phosphorus @ $100 \mathrm{~kg} / \mathrm{ha}$, while lowest value (9.81 t/ha) was recorded under the application of nitrogen @ 75 kg/ha with application of phosphorus @ $50 \mathrm{~kg} / \mathrm{ha}$.

Mineral nutrients like nitrogen may exert its influence on flowering initiation by increasing the rate of photosynthesis and export of solute to his sink site. Nitrogen resulted the vegetative growth and have been used also effective in flowering and fruiting characters. On the contrary, it induced earlier flowering and fruiting, this is perhaps due to the fact that nitrogen induced the complete growth phase of okra earlier, resulting in earlier flowering and fruiting. 
Use of nitrogen in this investigation favoured the vegetative growth and number of flowers borne was proportionately high. It may be pointed out that relatively large number of auxins and various other substances regulating the lower bud initiation are produced by the foliage and hence applied nitrogen seems to have positive correlation with the number of lowers borne.

Thus, it is clear that yield of pod in tonnes per hectare was the maximum at $150 \mathrm{~kg} \mathrm{~N} / \mathrm{ha}$ due to the highest values of yield attributing characters. Patton et al., (2002) and Shanke et al., (2003) in different regions also indicated similar increase in pod yield attributing characters at higher levels of nitrogen probably due to the fact that higher nitrogen stimulated the assimilation of carbohydrates and proteins which in turn enhanced cell division and formation of more tissues resulting in luxuriant vegetative growth and more photosynthetic area and thus the taller plants. This increased the photosynthetic area and favourable physiological activities under higher nitrogen levels since to have resulted in more production and translocation of photosynthesis in plants, which subsequently accelerated the formation of more number of large size fruits. These results were in conformity with the finding of Yadav et al., (2016) and Narendra et al., (2017).

Phosphorus is also one of the important nutrients required by plants for proper growth and development for getting higher yield. It is an important constituent of nuclear proteins and enzymes. The application of phosphorus as used present investigation influenced significantly the growth attributes like plant height, spread of plant, diameter of stem and number of leaves per plant. Each increase in the level of phosphorus on 50 to $100 \mathrm{~kg} / \mathrm{ha}$ increased the amount of these attributes correspondingly. The highest value of these attributes was recorded with $100 \mathrm{~kg} \mathrm{P2O5/ha.}$
For the formation of nucleic acid, nucleoprotein and lecithin which are present in almost all the living cells, phosphorus is essential. Particularly all phosphorus is absorbed by the plant in the form of phosphorus.

Similar to our results, Patton et al., (2002) also observed significant effect on vegetative growth, flowering and yield. Singh (2001), reported that phosphorus fertilization significantly increased yield attributes and pod yield. These findings confirm the present results. This was also due to the beneficial effect at optimum level of phosphorus i.e. 100 $\mathrm{kg} / \mathrm{ha}$, which might be due to the stimulating effect of phosphorus on plant processes, viz. cell division and root elongation in meristematic tissues and constituent of ADP and ATP in plant, which plays an important role in energy storage.

With increase in photosynthetic products, coupled with efficient translocation, plant produced more pods/ plant. The significant increase fruit yields appeared to be on account of beneficial effects of nitrogen and phosphorus on growth and yield attributes which finally reflected in higher fruit yield of okra. These results were in conformity with the finding of Yadav et al., (2016) and Narendra et al., (2017).

Based upon this experiment it is concluded that application of higher level of nitrogen at the rate of $150 \mathrm{~kg} / \mathrm{ha}$ combined application with phosphorus at the rate of $100 \mathrm{~kg} / \mathrm{ha}$ recorded the maximum growth and grain yield of okra for the agro-climatic conditions of central Madhya Pradesh The significant improvement in the fruit yields of okra with the application of nitrogen appears to be cumulative effect of greater uptake and translocation of nitrogen during reproductive and fruiting stage. 


\section{References}

Bairwa, H.L., L.N., Mahawer, A.K., Shukla, R.A., Kaushik, Mathur, S.R. (2009). Response of integrated nutrient management on growth, yield and quality of okra. Indian J. Agri. Sci. 79 (5): 381-384.

Bhende, S.K., Deshmukh, H. K., Nimbolkar, P. K., Dewangan, R. K., Nagone, A.H. 2015. Effect of phosphorous and potassium on quality attributes of okra cv. 'Arka Anamika'. International journal of environmental sciences, 6 (2): 225- 231.

Firoz, Z. A. 2009. Impact of nitrogen and phosphorus on the growth and yield of okra (Abelmoschus esculentus (L) Moench.) in hill slope condition. $J$. Agri. Res. 34 (4): 713- 722.

Khan, M. A., Sajid, M., Hussain, Z., Rab, A., Khan, B. M., Wahid, F. I. and Bibi, S. 2013. How nitrogen and phosphorus influence the phenology of okra. J. Bot. 45 (2): 479- 482.

Khan, M. S. I., Roy, S. S. and Pall, K. K. 2010. Nitrogen and phosphorus efficiency on the growth and yield attributes of capsicum. Academic $J$. Plant Sci. 3 (2): 71-78.

Memon, K. S. 1996. Soil and fertilizer. National Book Foundation, Pp: 292316.

Mubashir, M., Malik, S. A., Khan, A. A., Ansari, T. M., Wright, S., Brown, M. V. and Islam, K. R. 2010. Growth, yield and nitrate accumulation of irrigated carrot and okra in response to nitrogen fertilization. J. Bot. 42 (4): 2513- 2521.

Narendra Kumar Meena, Rajesh Kumar Meena, R. S. Dhaka, and Om Prakash Meena, 2017. Response of Nitrogen, Phosphorus and Potassium Levels on Growth and Yield of Okra (Abelmoschus esculentus (L.) Moench) cv. Arka Anamika. Int. J. Pure App.
Biosci. 5 (4): 1171-1177.

NHB (2014). National Horticulture Database - 2014. National Horticulture Board Government of India, Gurgaon, India. www.nhb.gov.in.

Pandey, V.B. and Dubey, R.P. (1996). Effect of nitrogen, phosphorus and intra-row spacing on quality and chemical composition of okra. Indian J. Hort. 53 (2): 141- 144.

Patton, W., Sema, A. and Maiti, C.S. (2002). Effect of different levels of nitrogen and phosphorus on growth, flowering and yield of okra cv. Arka Anamika grown under the foothills of Nagaland. The Hort. J. 15 (1): 81-88.

Shanke, B.R., Jadao, B.J., Ghawade, S.M. and Mahorkar, V.K. (2003). Effect of different level of $\mathrm{N}$ and $\mathrm{P}$ on growth and seed yield of okra (cv. Parbhani Kranti), under Akola condition. The Orissa J. Hort. 31 (1): 123-124.

Shelar, R.B., Kadam, A.S., Patil, V.K. and Narsude, P.B. 2011. Studies on effect of different sources of nitrogen on growth and yield of okra (Abelmoschus esculentus (L.) Monech). International Journal of Agriculture Science, 7 (1): 70-73.

Sikander, A., Dawar, S., Tariq, M. and Zaki, M. J. 2009. Management of root diseases by Combination of different soils with fertilizers. J. Bot. 41 (6): 3219- 3225.

Singh, R.V. (2001). Effect of intercrop and N, $\mathrm{P}$ fertilization on performance of okra (Abelmoschus esculentus). Journal of Research Birsa Agricultural University, 13: 325-327.

Srivastava, B.K., M.P., Singh, Sobaran Singh, Shashilata, Pankaj Srivastava, Shahi, U.P. (2009). Effect of Integrated nutrient management on the performance of the crop under brinjalpea-okra cropping system. Indian $J$. Agri. Sci. 79 (2): 91-93. 
Veer Bhan Singh and Anil Kumar Tiwari, 2019. Effect of Integrated Nutrient Management (INM) on PhysicoChemical Properties of Soil, Available Content and Nutrient Uptake by Okra (Abelmoschus esculentus). International Journal of Current Microbiology and Applied Sciences, 8 (3): 130- 137.
Yadav, S.C., Yadav, G.L., Gupta, G., Prasad, P.M. and Bairwa, M. 2016. Effect of integrated nutrient management on quality and economics of okra (Abelmoschus esculentus (L.) Moench). International Journal of Farm Sciences, 6 (3): 233-237.

\section{How to cite this article:}

Chandan Singh Ahirwar, Avadhesh Pratap Singh, Ravindra Nath and Verty, P. 2021. Assessments Effect of Nitrogen and Phosphorus on the Phenological and Fruit Characters of Okra (Abelmoschus esculentus L.). Int.J.Curr.Microbiol.App.Sci. 10(02): 1918-1925. doi: https://doi.org/10.20546/ijcmas.2021.1002.229 